\title{
The Structure of the Female Strobilus in Gnetum Gnemon.
}

\author{
BY \\ EMILY M. BERRIDGE, B.SC., F.L.S. \\ With four Figures in the Text.
}

JERY full and detailed accounts of the vascular supply to the flowers of various species of Gnetum have recently been published, ${ }^{1}$ but in no case apparently do the ovules investigated show a certain series of complexes which constitute a striking feature in the vascular system of the female 'flower' of Gnetum Gnemon.

In this species, as in other Indo-Malayan forms, ${ }^{2}$ the $12-14$ bundles which traverse the base of the female flower all spring from the bundles which supply the cupule, and only a very few late-formed branches originate directly from the main vascular system of the inflorescence. Each of these bundles, on reaching the level of insertion of the outermost of the three coats of the ovule, becomes very broad and gives off two traces to this outer coat or 'perianth'; then turning inwards and upwards each passes on to supply the two inner coverings, which are probably best regarded as integuments.

Just above the point of departure of the two traces to the outermost coat (Fig. I, $p_{1}, p_{2}$ ) each main bundle gives rise to a curious complex of vascular strands.

Fig. 2 shows a tangential section of one of these, while Figs. 3 and 4 , representing two sections through a single complex, show more clearly the relative positions of the main bundle, $m$., the traces $p_{1}, p_{2}$ passing to the outermost covering of the ovule, the complex, $c_{\text {. }}$, and the main bundle, int., passing on towards the integuments.

Although, as in this case, the complexes often take the form of loops, they also frequently consist of three or four vascular strands, which end

Thoday, M. G. ('11) : The Female Inflorescence and Ovules of Gnetum Africanum, with notes on Gnetum scandens. Ann. of Bot., xxv, p. I Ior. Pearson, H. H. W. : The Microsporangium and Microspore of Gnetum. Ann. of Bot., xxvi, p. 6I4.

Thoday, M. G. : Note on the Inflorescence Axis of Gnetum. Ann. of Bot., xxvi, p. 62 I.

[Annals of Botany, Vo1. XXVI. No. CIV. October, 1912.] 


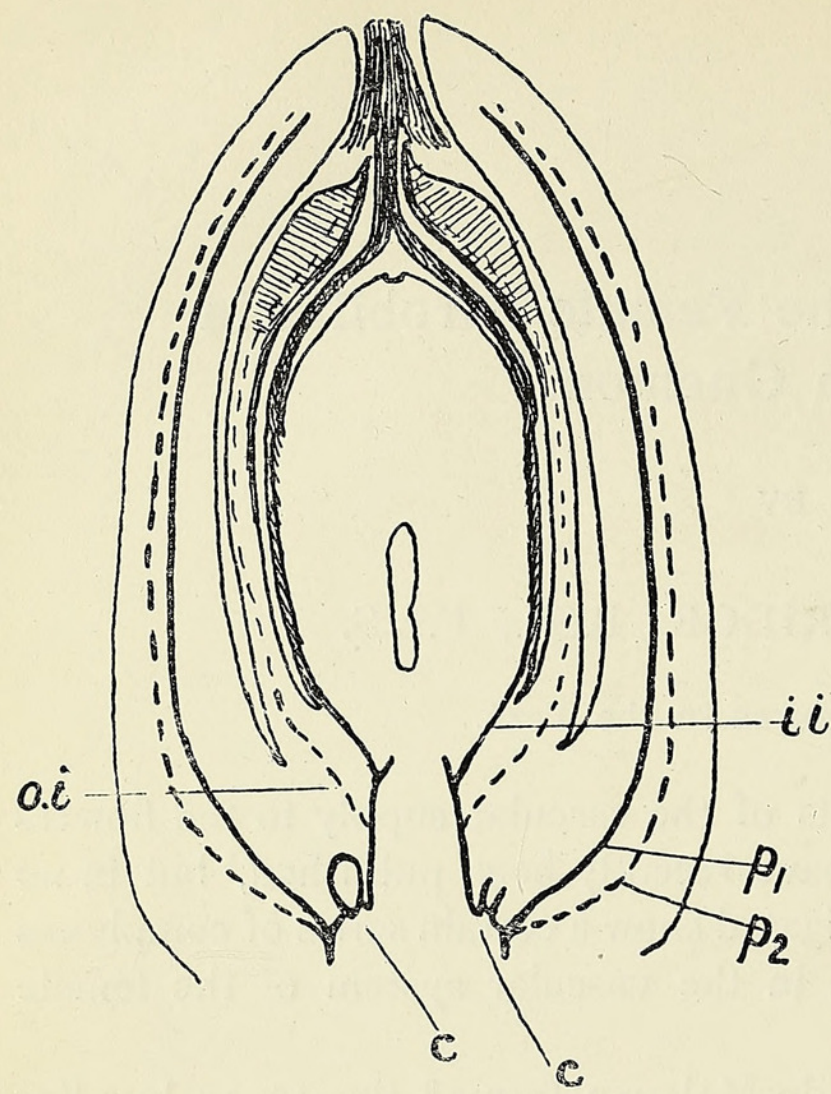

FIG. I. Longitudinal section through young seed of Gnetum Gnemon. $p_{1}, p_{2}$, bundles supplying outermost coat; $0 . i$., bundle supplying outer integument; i.i., bundle supplying inner integument; $c_{\text {., }}$ complex of vascular strands. The bundles indicated by dotted lines do not lie in the plane of the section.

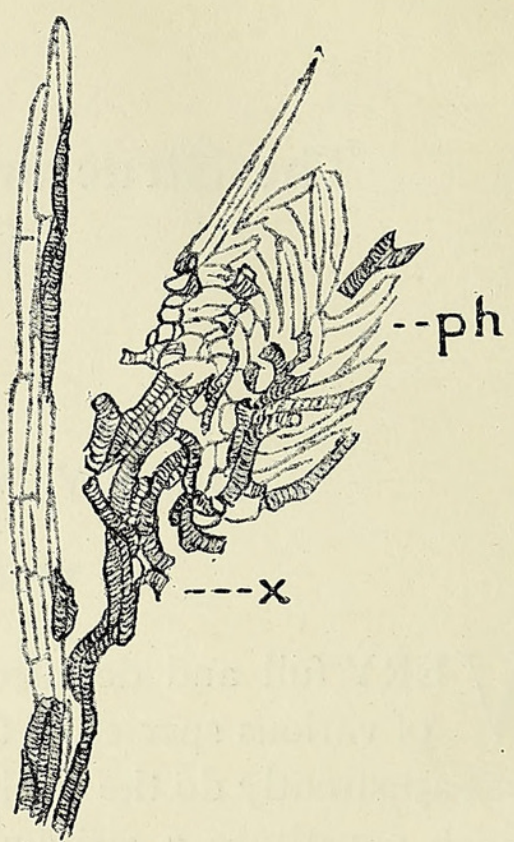

FIG. 2. Tangential section of a single vascular complex. $x$, xylem; ph., phloem.
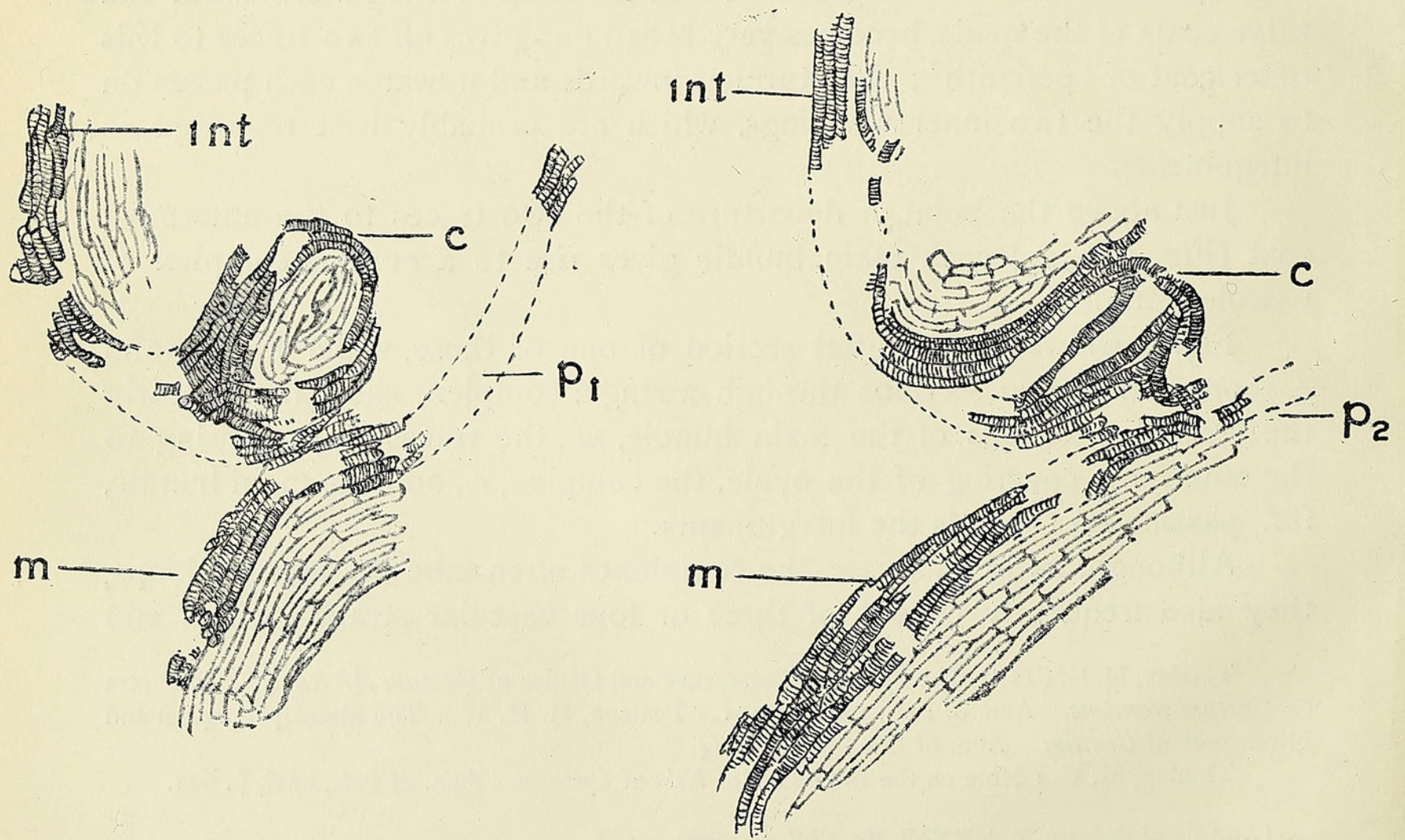

FIG. 3. Longitudinal sections through a single vascular complex. m., main bundle; $p_{1}, p_{2}$, bundles to outermost coat ; $c_{0}$, complex; int., bundle to integuments. 


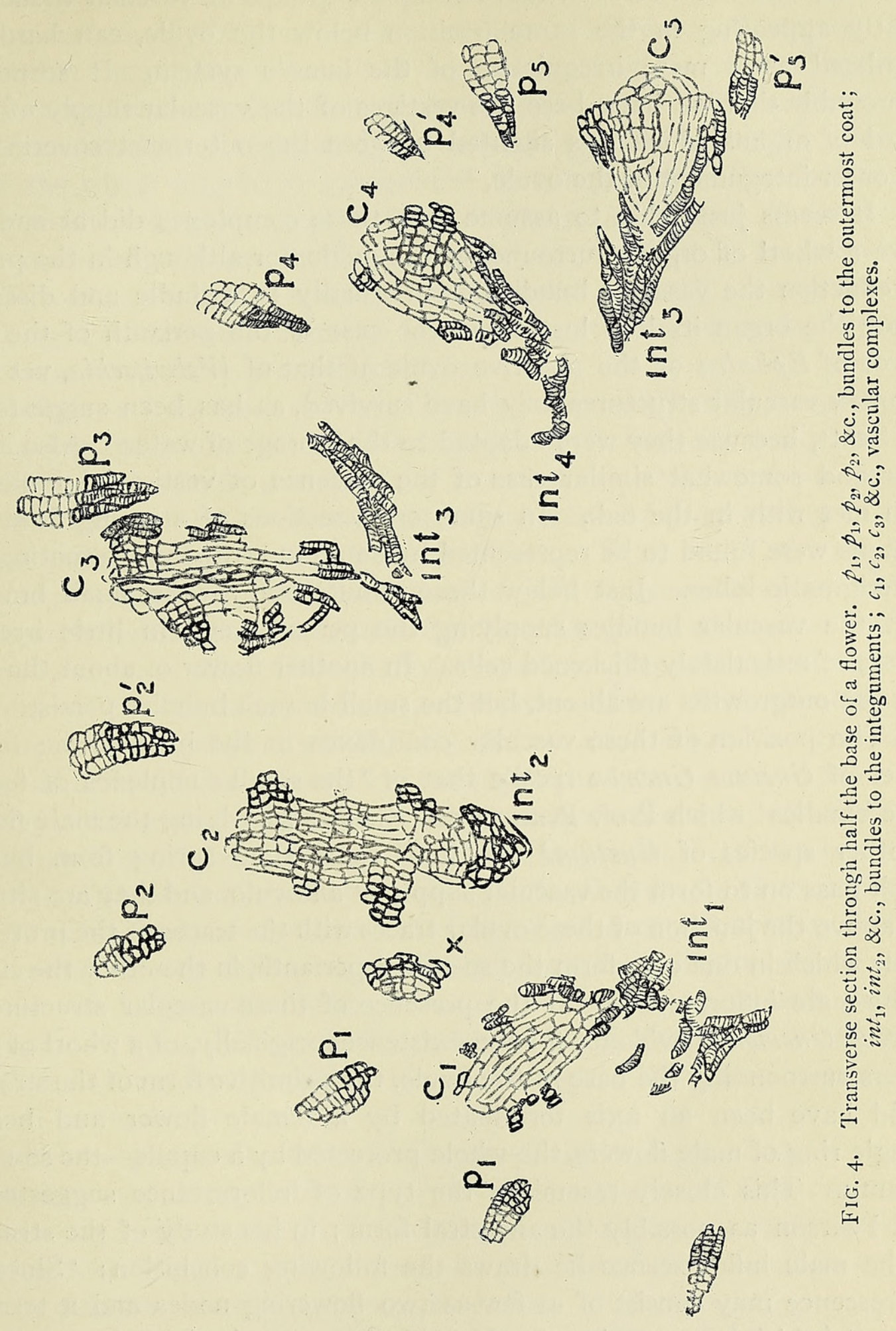

blindly in the tissue below the groove between the second and third coats of the ovule.

In Fig. 4 the vascular complexes are shown as they appear in a crosssection through the base of the flower. They always contain a considerable mass of phloem, but the xylem tends to break up into separate strands, and in some cases, as at $x$, independent bundles are formed. 
This whorl of twelve or more complex groups of vascular tissue, constantly appearing in the same position below the ovule, can hardly be dismissed as a mere irregularity of the bundle system. It seems not improbable that we have here the vestiges of the vascular supply of some whorl of organs which was situated between the outermost covering and the outer integument of the ovule.

It seems justifiable to assume that these complexes did at one time serve a whorl of organs surrounding the ovule, for although in the process of reduction the vascular bundles seem usually to dwindle and disappear before the organ itself is lost, as in the case of the perianth of the male flower of Ephedra or the abortive ovule of that of Welwitschia, yet these complex vascular structures may have survived, as has been suggested by Dr. Scott, because they were adapted to the storage of water. Also a very clear and somewhat similar case of the presence of vestigial bundles has been met with in the oak. In some cross-sections of a young flower the stamens were found to be represented by small outgrowths alternating with the stigmatic lobes. Just below these minute outgrowths, small branches from the vascular bundles supplying the perianth end in little irregular masses of reticulately thickened cells. In another flower of about the same age, the outgrowths are absent, but the small branch bundles persist.

The position of these vascular complexes in the base of the female flower of Gnetum Gnemon recalls that of 'the small complexes of four or more bundles' which Prof. Pearson describes as supplying the male flowers in other species of Gnetum. ${ }^{1}$ In both cases they spring from bundles which pass on to form the vascular supply of an ovule, and they are situated just above the junction of these ovular traces with the traces of the protective bracts which in one case form the so-called perianth, in the other the cupule of the male inflorescence. If the presence of these vascular structures in Gnetum Gnemon is evidence for the existence, originally, of a whorl of male flowers surrounding the base of the ovule, the primitive form of the strobilus would have been an axis terminated by a female flower and bearing a single ring of male flowers, the whole protected by a cupule-the so-called perianth. This closely resembles the type of inflorescence suggested by Prof. Pearson as possibly the ancestral form ; in his study of the structure of the male inflorescence he draws the following conclusion: "Since the inflorescence may consist of as few as two flowering nodes and a terminal segment (which in some cases is an ovule with appendages) it is conceivable that the ancestral type of inflorescence was an axis bearing a single lateral ring of male flowers and a terminal female flower.'

The vascular knots may possibly have supplied a whorl of microsporophylls rather than complete male flowers; the female flower of Gnetum would then be comparable to the male flower of Welwitschia, and the presence 
of these vascular structures might be taken as evidence for the hypothesis that the whole family originally possessed bisexual flowers. There are indications that the organs in the whorl were grouped in four sets of approximately three members, for the main bundles just above the insertion of the complexes are linked together by anastomosing strands in this manner. Hence the whorl may have consisted of four members of threefold nature similar to the microsporophylls of the Welwitschia flower. The structure of the male inflorescence in Gnetum, however, points to an association of male flowers rather than of microsporophylls with the ovule; hence it seems best to regard the female flower as representing at the present day a partial inflorescence and not a proanthostrobilus.

It follows from such a view that the apparently simple spike now constituting the whole female inflorescence of Gnetum is really of compound nature, consisting primitively of a central axis with a series of cupules from the axils of which sprang secondary axes bearing a ring of male flowers and a single terminal female flower. From such a compound inflorescence, moreover, could be derived an inflorescence closely resembling; both morphologically and anatomically, the male spikes of Gnetum Gnemon, $G$. scandens, and other Indo-Malayan species. Suppression of the first internode of the secondary axis, a modification which constantly occurs in many species of Ephedra, would bring the terminal female flower and the ring of male flowers into the axil of the cupule, and the outermost protective covering of the partial inflorescence, being now unnecessary, would disappear. The shortening of the first internode of the vegetative branches is accompanied in Ephedra altissima and frequently in E. nebrodensis by a shifting of the axillary buds of the first node from their normal lateral position to the abaxial side of the branch. The suppression of the internodes in the branches of the primitive inflorescence of Gnetum may have been similarly accompanied by a shifting of the male flowers so that they have become crowded together in the axil of the cupule below the abortive ovule, and reduced in number.

In the vegetative branches of Gnetum Gnemon suppression of the first internode is not clearly evident, but the presence of small buds in the axil between the branch and its subtending leaf, basipetally developed and deriving their vascular supply from the bundles of the branch alone, may indicate that the same thing occurs here also.

It seems probable therefore that Gnetum originally bore compound bisexual inflorescences from which both male and female spikes have been derived. The former have preserved in certain Indo-Malayan species their bisexual character, but the latter have as a rule lost all trace of it, for the strobilus of Gnetum Gnemon alone, as far as is known, retains in its series of vascular complexes surrounding the base of the ovule some vestige of its original complicated structure. 
992 Berridge.-Structure of Female Strobilus in Gnetum.

\section{SUMMARY.}

The presence of a ring of complex groups of vascular strands arising from the bundles in the base of the female 'flower' of Gnetum Gnemon may indicate that the ovule was primitively surrounded by a whorl of male flowers. If this were the case the female inflorescence of Gnetum would have been originally compound and bisexual, and from such a form the existing male inflorescence can easily be derived. 


\section{$2 \mathrm{BHL}$ Biodiversity Heritage Library}

Berridge, Emily Mary. 1912. "The structure of the female strobilus in Gnetum gnemon." Annals of botany 26, 987-992.

https://doi.org/10.1093/oxfordjournals.aob.a089440.

View This Item Online: https://www.biodiversitylibrary.org/item/236930

DOI: https://doi.org/10.1093/oxfordjournals.aob.a089440

Permalink: https://www.biodiversitylibrary.org/partpdf/319943

\section{Holding Institution}

Smithsonian Libraries

\section{Sponsored by}

Biodiversity Heritage Library

\section{Copyright \& Reuse}

Copyright Status: Not in copyright. The BHL knows of no copyright restrictions on this item.

This document was created from content at the Biodiversity Heritage Library, the world's largest open access digital library for biodiversity literature and archives. Visit BHL at https://www.biodiversitylibrary.org. 